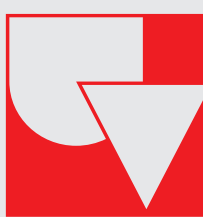

Universidad del Valle

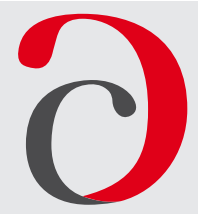

Cuadernos de

Administración
Journal of Management

Print ISSN: 0120-4645 / E-ISSN: 2256-5078 / Short name: cuad.adm.

Pages: 93-108 / Vol: 36 / Issue: 67 / May - Aug. 2020

Faculty of Administration Sciences / Universidad del Valle /

Cali - Colombia

\title{
Mining and Energy Commodity Price Effects on Colombian Economy
}

\author{
Efectos de los precios de los commodities minero-energéticos \\ sobre la economía colombiana
}

\begin{abstract}
${ }^{1}$ Andrés Oviedo-Gómez $\mathbb{D}$
Engineering Doctorate Student, Universidad del Valle, Cali, Colombia. e-mail: oviedo.andres@correounivalle.edu.co
\end{abstract}

\section{Juan Manuel Candelo-Viafara(D)}

Professor, School of Management Sciences, Universidad del Valle, Buga, Colombia.

e-mail: juan.candelo@correounivalle.edu.co

\section{Abstract}

Article of Scientific and Technological Research

Submitted: 04/11/2019

Reviewed: $28 / 02 / 2020$

Accepted: 18/05/2020

Thematic lines: Economy and International Trade JEL classification: F14, F41, 054

DOI: https://doi.org/10.25100/cdea.v36i67.8641

The Colombian economy has a strong dependence on the export of commodities. Different studies show that the prices of these products are exogenous, which have originated direct effects on the national economic activity. Therefore, this paper studies the shock effects produced by mining and energy commodity price variations like oil, coal and nickel on Colombian economy. We used 129 variables for 2001-2016 period and estimated a FAVAR model (Factor Augmented VAR) to observe commodity price effects on different economic aggregates, the results show that price fluctuations have significant effects on variables such as economic activity, investment, the trade balance, the real exchange rate and external debt.

Keywords: Commodity prices, Economic activity, International trade, Time series analysis, FAVAR model.

\section{Resumen}

La economía colombiana se caracteriza por tener una fuerte dependencia en la exportación de materias primas. Diferentes estudios muestran que los precios de estos productos están dados de manera exógena, lo que origina efectos directos sobre la actividad económica de los países. Por lo tanto, este trabajo evalúa la incidencia de los choques producidos por las variaciones de los precios de los bienes minero-energéticos con mayor peso en las exportaciones colombianas, es decir, el petróleo, el carbón y el níquel. Para observar los efectos que tienen sobre los diferentes agregados económicos, se empleó una base de datos compuesta por 129 variables para el periodo $2001-2016$ y se estimó un modelo FAVAR (Factor Augmented VAR, por sus siglas en inglés). Los resultados hallados permiten inferir que las fluctuaciones de los precios tienen incidencias significativas sobre variables como la actividad económica, la inversión, la balanza comercial, el tipo de cambio real y la deuda externa.

Electronic Engineer, Pontificia Universidad Javeriana, Colombia, Master in Applied Economics, Universidad del Valle, Colombia.

2 Business Manager, Master in Applied Economics, Universidad del Valle, Colombia. 
Palabras clave: Precios de materias primas, Actividad económica, Comercio internacional, Análisis de series cronológicas, Modelos FAVAR, Colombia.

\section{Introduction}

Latin American countries have been characterized by having a high dependence on the production of raw materials in their exports, which has resulted in their economies being exposed to fluctuations generated by the prices of commodities (Castillo and Salas, 2010). The Colombian economy is not immune to these variations, in fact, Jenkins (2011) observed that the increase in the demand for basic goods by Asian countries, between 2001 and 2007, generated an increase in its foreign exchange earnings for Colombia of almost 10\%. However, Vargas (2015) explained that the slowdown in demand for raw materials in mid-2008 and the subsequent fall in the price of oil in 2014, produced a reduction in national income, which increased the current account deficit of the balance of payments and caused an unprecedented depreciation of the national currency.

Additionally, for Colombia, fluctuations in the prices of raw materials are of great importance, considering that exports for 2015 represented 15\% of GDP (The World Bank Group, 2016) and that $80 \%$ of them were basic products, where oil (40\%), coal $(13 \%)$ and nickel $(1 \%)^{1}$ constitute more than half of national exports (Consejo Privado de la Competitividad, 2014). Therefore, it is important to study the effects generated by the prices of the mining-energy products exported by Colombia on economic activity and to determine which are the variables that directly receive this impact.

Given the above, the objective of this research is to evaluate the effects caused by variations in oil, coal and nickel prices on Colombian macroeconomic variables, mainly on production, investment, the trade balance, the exchange rate, and foreign debt. In addition, this paper seeks to provide an alternative analysis to the research carried out by Oviedo and Sierra (2019). The methodology applied in this analysis is called FAVAR (Factor Augmented VAR), developed by Bernanke, Boivin, and Eliasz (2005). The most outstanding results indicate significant effects on variables such as economic activity, investment, the trade balance, the real exchange rate, and external debt.

The work is divided into the following sections: section 2, reviews the literary references; Section 3 describes the evolution of the prices of exported commodities and their relationship to the economy; Section 4 presents information on the applied empirical methodology; in section 5, a description of the data is made and section 6 , discloses the results. Finally, section 7 presents the conclusions.

\section{Literature Review}

Different international and national studies have shown the importance of variations in raw material prices on economic aggregates, based on the use of the terms of trade ${ }^{2}$ (TOT) or oil prices, both in developed and ongoing economies developmental. At the international level, Mendoza (1995) analyzed the effects of the oscillations in the terms of trade on the business cycle for developed and emerging countries. The results show that TOT variations explain GDP fluctuations by $37 \%$ in developing countries, while in developed countries they do so by $33 \%$. On the other hand, Fernández, González, and Rodríguez (2015) analyzed the incidence of commodity prices on the economic cycles of emerging countries and found that a positive shock generates positive and significant effects on GDP, investment and consumption and a negative and significant effect on the real exchange rate (RER) index. Meanwhile, Spatafora and Warner (1999) determined for a group of 18 oil exporting countries that the incidence of TOT variations on GDP, consumption and investment is $30 \%$. However, Schmitt-Grohé and Uribe (2015) analyzed the effects of TOT for 38 emerging economies and found that the variations affect production, consumption and investment by $10 \%$.

On the other hand, fluctuations in the prices of raw materials affect not only the prices of industrial products (Regnier, 2007), but also generate variations in the use of

1 The information was obtained directly from the National Administrative Department of Statistics (DANE).

2 Oviedo and Sierra (2019) found that TOT has a positive correlation of 0.88 with oil prices in Colombia. 
production factors, mainly at work, thanks to the intensity in the use of labor and capital (Hamilton, 1988; Bretschger, 2015; Lee and $\mathrm{Ni}, 2002$ ), which influences the competitiveness of the sectors that produce tradable goods in the international market. Therefore, the shocks of commodity prices can generate involuntary unemployment in sectors that lose competitiveness due to the inflow of foreign currency (Hamilton, 1988; Lilien, 1982).

For its part, Latin America has been characterized by a high dependence on the production of raw materials for export, so much so that by 2014 , total exports of these products exceeded $60 \%$ in the whole southern region of the continent. Medina (2010) identified that a commodity price shock produces a significant and positive impact on government consumption, which extents 3 quarters on the Latin American economies. While, Ben-Zeev, Pappa, and Vicondoa (2016), identified that TOT generates, approximately, $25 \%$ of the fluctuations of the production of Brazil, Mexico, Chile, Colombia, Ecuador, Argentina, and Peru. Similarly, at the country level, Castillo and Salas (2010) for Peru and Peña $(2008,2015)$ for Venezuela, found that increases in raw material prices affect variables such as GDP, employment rate, consumption, and investment.

At the Colombian level, several studies have shown the effects of variations in the prices of commodities and oil on variables such as production, investment, the real exchange rate, or inflation. Oviedo and Sierra (2019), based on a FAVAR model, determined that TOT variations generate an increase in economic activity and the trade balance and a decrease in the real exchange rate. However, they observed that the investment presented an equivalent variation of $8 \%$ due to a positive fluctuation in the prices of raw materials. On the other hand, and in line with the results described above, Hernández (2013) evaluated the fluctuations of TOT on GDP and concluded that 33\% of the quarterly variability of GDP depends on TOT.

On the other hand, and when reviewing the effects of oil prices in Colombia, González and Hernández (2016) identified positive and significant effects on GDP, on the TOT index, on the trade balance, and on foreign direct investment and a negative response from the RER (real appreciation). According to the previous results, Gómez (2015) concludes that a positive oil price shock generates a positive and significant effect on GDP and the CPI, but observes significant negative effects on external public debt. At the regional level, for the department of Valle del Cauca, Candelo (2018) observed, through an Error Correction Vector model (VECM) and a VAR model, that an increase in oil prices causes a slowdown in GDP regional, which deteriorates consumption, due to the high income of foreign remittances in the region. It would be convenient to study the incidence of commodity prices at the local level to understand their economic dynamics and compare the response of regional economic aggregates with the country's global economic aggregates, in the face of the shocks of these exogenous variables.

Despite the evidence found at the level of empirical studies, this research seeks to give continuity to the study carried out by Oviedo and Sierra (2019), to expand the results found on the impact that variations in commodity prices have on economic activity Colombia, based on the price discrimination of the three mining-energy goods with the greatest weight in national exports.

\section{Importance of Commodity Prices on the Economy}

As it has been observed, the Colombian economy is characterized by a high dependence on the production of raw materials in its exports, mainly in products belonging to the mining and energy sector. It has been established that, by the year 2015, $40 \%$ of exports were oil, $13 \%$ coal, $7 \%$ coffee and $1 \%$ nickel, so it is extremely important to understand the dynamics of the prices of these products over the last decades, because the most relevant effects are captured in economies that concentrate their exports in mineral-energy goods, followed by exporters of other raw materials and manufactured goods, as indicated by Sinnott, Nash, and De la Torre (2010).

Graph 1 describes the production of oil, coffee, coal, and nickel exported annually as a proportion of total national exports, 
Graph 1. Exported coffee, coal, oil, and nickel production as a total proportion of exports in Colombia, based on their price for 1980-2016
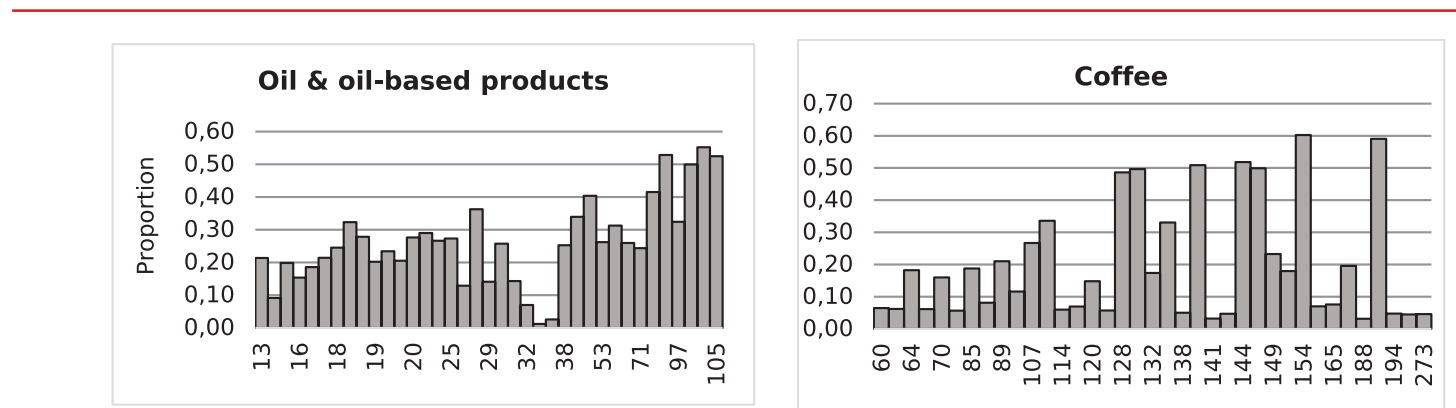

Prices evolution (USD)
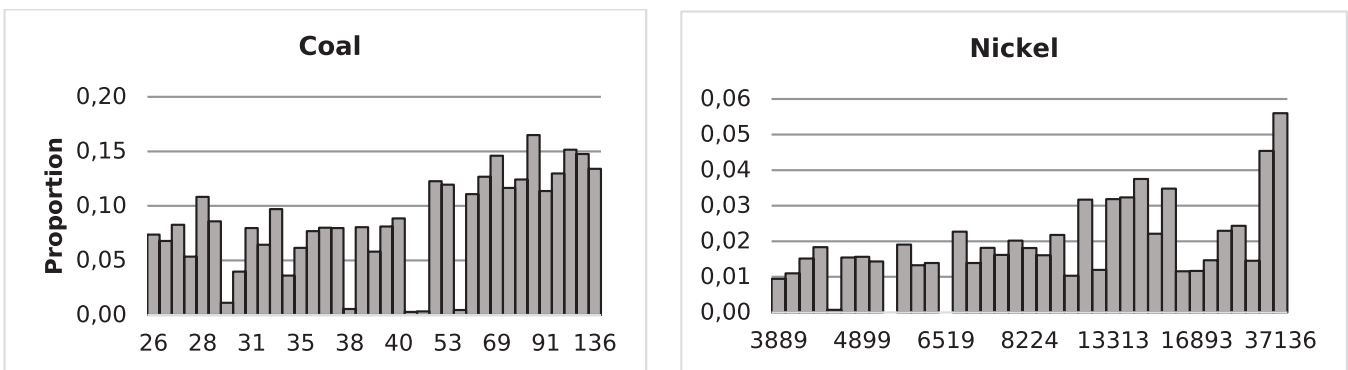

Prices evolution (USD)

Source: The report is based on data obtained from Banco de la República (2020).

based on the evolution of their prices ${ }^{3}$, for the period 1980-2016. In the first place, after analyzing the behavior of the participation and the prices of coffee and oil, it is possible to affirm that these raw materials are the ones with the greatest weight in national exports over the last decades. In fact, since 1970 after the coffee boom in Colombia, coffee became the most important export product, because it represented $50 \%$ of total exports (Cano, Vallejo, Caicedo, Amador, and Tique, 2012). However, in the middle of 2000, oil and coal increased their share of exports and have been the most important goods for Colombia. As evidenced, the proportions of these two products have had a constant value for the highest prices achieved, while coffee has presented significant price increases, although the proportion tends to be lower and highly variable. Finally, small increases can be found in the share of nickel over other exports, as its price increases.

In relation to nickel prices, it shows a similar behavior to oil prices. On the one hand, it can be inferred that the dynamics of these prices has been increasing in the middle of 2000, mainly due to the increase in demand for commodities in Asian countries and a subsequent fall at the end of the year.

Graph 1. Exported coffee, coal, oil, and nickel production as a total proportion of exports in Colombia, based on their price for 1980-2016.

According to authors such as Oviedo and Sierra (2019), Fernández et al. (2015), Medina (2010), and Hernández (2013), who have shown the variations in commodity prices both individually and through the use of the TOT variable, it has been observed that these exogenous shocks generate effects on internal variables such as: GDP, investment, trade balance, RER, inflation, and external debt. Therefore, by observing Table 1, correlations between the prices of mining and energy commodities and the described variables of interest are identified. It can be seen that all prices have a positive relation to GDP, investment, and trade balance and a negative relation to RER, inflation, and foreign 


\begin{tabular}{|l|c|c|c|c|c|c|}
\hline \multicolumn{7}{|c|}{ Table 1. Correlations between commodity prices and interest variable } \\
\hline \multicolumn{1}{|c|}{ Variables } & GDP & Investment & Trade balance & RER & Inflation & Foreign debt \\
\hline P. of Oil & 0.62 & 0.64 & 0.81 & -0.88 & -0.66 & -0.45 \\
\hline P. of Coal & 0.52 & 0.54 & 0.72 & -0.82 & -0.49 & -0.44 \\
\hline P. of Nickel & 0.7 & 0.71 & 0.85 & -0.86 & -0.71 & -0.43 \\
\hline \multicolumn{7}{|c|}{ Source: Authors' own elaboration. } \\
\hline
\end{tabular}

debt. Parra (2008) states that commodity shocks, measured through TOT, generate increases in production and investment due to the reallocation of capital to its productive place. In the case of the trade balance, the positive correlation is determined by the fact that the increase in the prices of these products encourages an increase in exports. On the other hand, the present negative relationship with the RER is consistent with the results found by Poncela, Senra, and Sierra (2016) who infer that the income derived, for example, from the increase in the price of oil generates an inflow of foreign currency that causes the real appreciation of the peso against the dollar. Finally, Gil (2016) found that commodity price shocks on Latin American economies do not generate significant effects on inflation and economic growth.

One of the most common negative effects of rising commodity prices on export economies is Dutch disease. This effect refers to the decrease in non-mining industrial competitiveness due to the fact that domestic products become relatively more expensive due to the devaluation of the dollar, which is the result of strong foreign exchange earnings. However, Poncela et al. (2016) identified for Colombia, that variations in commodity prices produce a currency revaluation, but not an industrial deterioration.

\section{Methodology}

The following is a description of the empirical methodology applied to identify the effects of price shocks of the three most important commodities on national exports.

\subsection{FAVAR Models}

The FAVAR Model can be written as the VAR model described by equation [1]:

$$
\left[\begin{array}{l}
\boldsymbol{F}_{t} \\
\boldsymbol{Y}_{t}
\end{array}\right]=\boldsymbol{\Phi}(\boldsymbol{L})\left[\begin{array}{l}
\boldsymbol{F}_{t-1} \\
\boldsymbol{Y}_{t-1}
\end{array}\right]+\boldsymbol{v}_{t}
$$

where the vector $Y_{t}$, of $M \times 1$ dimensions, is constituted by the set of observable economic variables: oil prices, coal prices, nickel prices, production, investment, trade balance, exchange rate, consumption, and inflation, for a $t=1,2, \ldots T$ periods. However, the VAR models exclude additional information that is relevant to interpret the dynamics of the series that constitute the vector. Therefore, the use of the vector $F_{t}$ is required, with $K \times 1$ unobservable factors, which summarizes the information that cannot be described by the vector $Y_{t}$. Additionally, $\Phi(L)$ represents the matrix of the finite lag polynomial of order $d$, and, $v_{t}$ is an error term with zero mediam and with a covariance matrix $Q$.

For the estimation of unobservable factors, the dynamic factorial models proposed by Geweke (1976) and extensively applied by Stock and Watson $(2002,2005,2011)$ are applied. Dynamic factorial models can be statically written by equation [2]:

$$
X_{t}=\Lambda F_{t}+e_{t}
$$

where $X_{t}$ is a vector of Nx1 dimensions, containing a large set of information. This vector is a function of the sum of two unobservable components: a component common to all variables, $F_{t}$, and an idiosyncratic component, $e_{t}^{4}$, proper to each variable. Whereas, $\Lambda$ is matrix composed of the factor loads, of dimension $N \times K$, and the term $\Lambda F_{t}$ is defined as the common components of $X_{t}$.

The estimation method of the FAVAR model applied in the research consists of finding the factors of the information set $X_{t}$ through 
principal components, and later including the estimated factors $\left(\widehat{\boldsymbol{F}}_{t}\right)$ in the VAR model (equation [1]). To find the number of factors that will be part of the vector $\widehat{\boldsymbol{F}}_{t}$ and that are included in the second part of the estimate, the information criteria proposed by Bai and $\mathrm{Ng}$ (2002) will be used.

\section{Data}

The database applied to this research was constructed by Oviedo and Sierra (2019) ${ }^{5}$ and is divided into two parts: the first part contains the series of interest such as the prices of mining-energy goods (oil, coal, and nickel), the product, investment, the trade balance, the exchange rate, and external debt. The second part is made up of 129 series that represent different sectors of the Colombian economy. The sectors are described as economic activity $(23)^{6}$, external sector (23), the real exchange rate (5), prices (31), monetary aggregates (16), total national employment (6), non-financial public sector (7), foreign investment flows in Colombia (12), and interest rates (6). The choice of the period was determined because it includes the boom in commodity prices in 2002 and its subsequent slowdown in 2008.

The series were reviewed one by one to eliminate atypical data, through the program TRAMO $^{7}$ (Gómez and Maravall, 2001) and they were transformed into dummy variables. On the other hand, it was sought that the matrix of variables $X_{t}$, was stationary.

\section{Empirical Results and Discussion}

Next, the results are presented from the estimation of the FAVAR model described by equation [1] and proposed by Bernanke et al. (2005). However, and before the results of the model, the estimation of the factors is made known through the methodology developed by Bai and $\mathrm{Ng}$ (2002).

\subsection{Estimation of the Number of Factors}

According to the information criteria of Bai and $\mathrm{Ng}$ (2002), it is found that the first two suggested the use of four factors and the third nine. Table 2 describes the results of the three penalty functions $I C_{1}, I C_{2}, I C_{3}$.

The first principal component that describes $18 \%$ of the variance proportion is

Table 2. Number of estimated factors

\begin{tabular}{|l|l|c|c|c|c|}
\hline Sample & Period & $\mathbf{N}^{\circ}$ Obs. & IC $_{\mathbf{1}}$ & IC $_{\mathbf{2}}$ & IC $_{\mathbf{3}}$ \\
\hline Complete & $2001 \mathrm{Q} 1-2016 \mathrm{Q} 1$ & 61 & 4 & 4 & 9 \\
\hline \multicolumn{4}{|c|}{ Source: Authors' own elaboration. } \\
\hline
\end{tabular}

selected as shown in Table 3 and is called the real exchange rate, due to the weight it has on the series ${ }^{8}$. The second factor explains about $16 \%$ of the variance and is named monetary aggregates, while the third factor, which explains about $13 \%$ of the variance, is named prices and the fourth factor, which describes $10 \%$, is named names economic activity. It is indisputable that the first four factors describe almost $57 \%$ of the total variance and from the fifth factor, the contribution of each one is lower, close to $5 \%$, which confirms the choice of four factors.

\section{2. Impulse Response Functions (IRF)}

Next, the estimates IRF $^{9}$ are presented from the FAVAR, which was described through the equation [1]. The model is characterized by containing in the vector, $Y_{t}$, the observable variables: oil prices $\left[O P_{t}\right]$, coal prices $\left[C P_{t}\right]$, nickel prices $\left[N P_{t}\right]$, investment $\left[I_{t}\right]$, trade balance $\left[T B_{t}\right]$, external debt $\left[E D_{t}\right]$,

$4 e_{t}$ of dimension $N \times 1$, is characterized by having zero mediam and normal distribution.

5 For more information on the database used, it is suggested to check Oviedo \& Sierra (2019).

6 The number of variables per category is denoted in parentheses.

7 TRAMO is available in the next link of Banco de España: http://www.bde.es/bde/es/secciones/servicios/Profesionales/Programas estadi/Programas estad d9fa7f3710fd821.html

8 The names of the factors were given from the values of the correlation (strong-high) that they presented with each of the variables used.

9 Generalized and accumulated Impulse Response Functions are estimated for a 95\% confidence interval and a period of 10 quarters. 


\begin{tabular}{|c|c|c|c|c|c|}
\hline \multicolumn{7}{|c|}{ Table 3. Factors found by Principal Component Analysis } \\
\hline $\mathbf{N}^{\circ}$ of factor & Value & Difference & Proportion & $\begin{array}{c}\text { Cumulative } \\
\text { Value }\end{array}$ & $\begin{array}{c}\text { Cumulative } \\
\text { Proportion }\end{array}$ \\
\hline 1 & 18.117920 & 2.40323 & 0.1342 & 18.11792 & 0.1342 \\
\hline 2 & 15.714690 & 2.41727 & 0.1164 & 33.83262 & 0.2506 \\
\hline 3 & 13.297420 & 3.52985 & 0.0985 & 47.13004 & 0.3491 \\
\hline 4 & 9.767571 & 3.08406 & 0.0724 & 56.89761 & 0.4215 \\
\hline 5 & 6.683512 & 0.945658 & 0.0495 & 63.58112 & 0.4710 \\
\hline 6 & 5.737855 & 0.587268 & 0.0425 & 69.31898 & 0.5135 \\
\hline \multicolumn{7}{|l}{ Source: Authors' own elaboration. } \\
\hline
\end{tabular}

unemployment rate $\left[U R_{t}\right]$, and government consumption $\left[G C_{t}\right]$. While the vector $\widehat{\boldsymbol{F}}_{t}$ is compound for two of the four estimated factors: the RER factor - $f_{1 t}$ and the economic activity factor $-f_{4 t}$. Oviedo and Sierra (2019) observed that monetary aggregates and prices do not present significant responses to positive shocks in the prices of exported goods, for this reason, the factors of monetary aggregates and prices were excluded from the model estimation. Furthermore, it was observed that for the factors $f_{1 t}$ and $f_{4 t}$ and at a time length of two lags, the assumptions about the residuals are robust and consistent (see Annex). Therefore, the generalized FIR was estimated under the assumption of normality of the conditional errors. From what has been described, equation [1] is rewritten as:

$$
\begin{gathered}
{\left[\begin{array}{l}
\widehat{\boldsymbol{F}}_{\boldsymbol{t}} \\
\boldsymbol{Y}_{t}
\end{array}\right]=\boldsymbol{\Phi}(\boldsymbol{L})\left[\begin{array}{l}
\boldsymbol{F}_{t-1} \\
\boldsymbol{Y}_{t-1}
\end{array}\right]+\boldsymbol{v}_{t}} \\
\boldsymbol{Y}_{t}{ }^{\prime}=\left[O P_{t}, C P_{t}, N P_{t}, I_{t}, T B_{t}, E D_{t}, U R_{t}, G C_{t}\right] \\
\widehat{\boldsymbol{F}}_{t}{ }^{\prime}=\left[f_{1 t}, f_{4 t}\right]
\end{gathered}
$$

\subsection{Impact of Oil, Coal, and Nickel Prices on Economic Activity}

Graph 2 shows the response of the economic activity factor to a positive shock in the prices of oil, coal, and nickel. It can be seen the three mining-energy assets generate positive and significant effects on the variable studied, but the duration differs. Oil prices produce economic growth that spans four periods, while coal prices cause an economic improvement observable one quarter after the shock, lasting three quarters. Finally, nickel prices increase economic activity for six quarters, but the effects are generated a period later. Oviedo and Sierra (2019) identified that a positive TOT shock causes an improvement in production that spans four quarters. The increase in the prices of these products increases the entry of foreign currency into the country, which increases the income of the export sector and encourages production. On the other hand, Parra (2008) explains that production increases thanks to an improvement in the income of the export sector.

\subsection{Impact of Oil, Coal, and, Nickel Prices on Investment}

Oviedo and Sierra (2019) indicated that the positive variation in investment occurs indirectly through fluctuations in the trade balance, which causes increases in income, and these in turn on investment. Graph 3 shows that investment responds positively and significantly to increases in the price of oil, however, the innovations in the prices of coal and nickel generate non-significant responses because the extraction of these minerals is not intensive in the capital.

The response spans a quarter and occurs in a post-shock period. The increase in income from the export sector generates incentives to request credits, after observing the increase in the mining-energy good price which translates into an increase in investment. 
Graph 2. The response of economic activity to a positive shock in oil, coal, and nickel prices

Accumulated Response to Generalized One S.D. Innovations \pm 2 S.E.
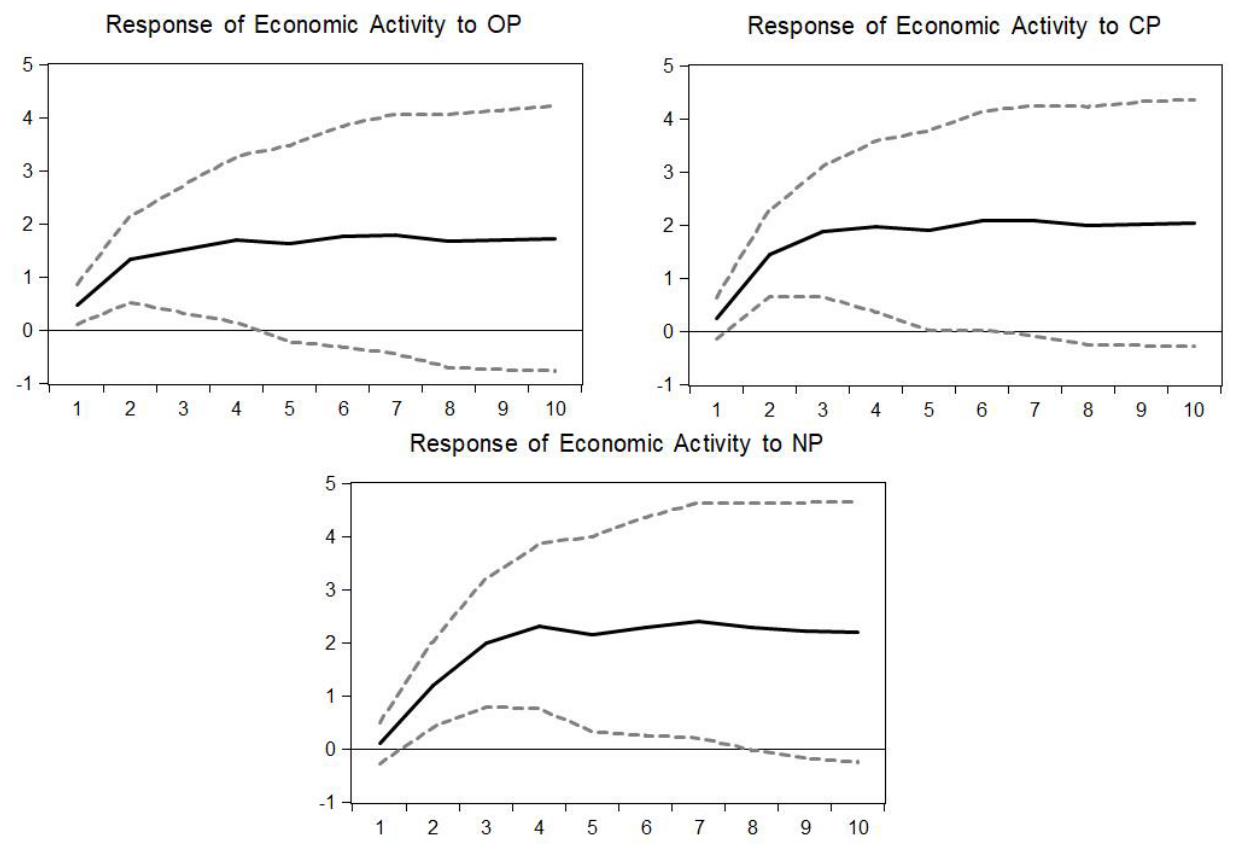

Source: Authors' own elaboration.

Graph 3. Investment response to a positive shock in oil, coal, and nickel prices

Accumulated Response to Generalized One S.D. Innovations \pm 2 S.E.

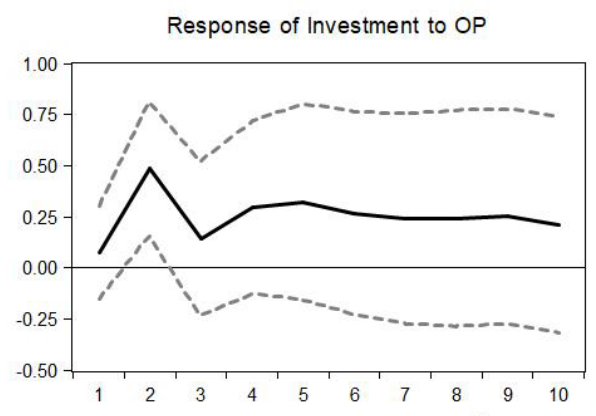

Response of Investment to $\mathrm{CP}$

Source: Authors' own elaboration. 
Graph 4. The exchange rate response to a positive shock in oil, coal, and nickel prices

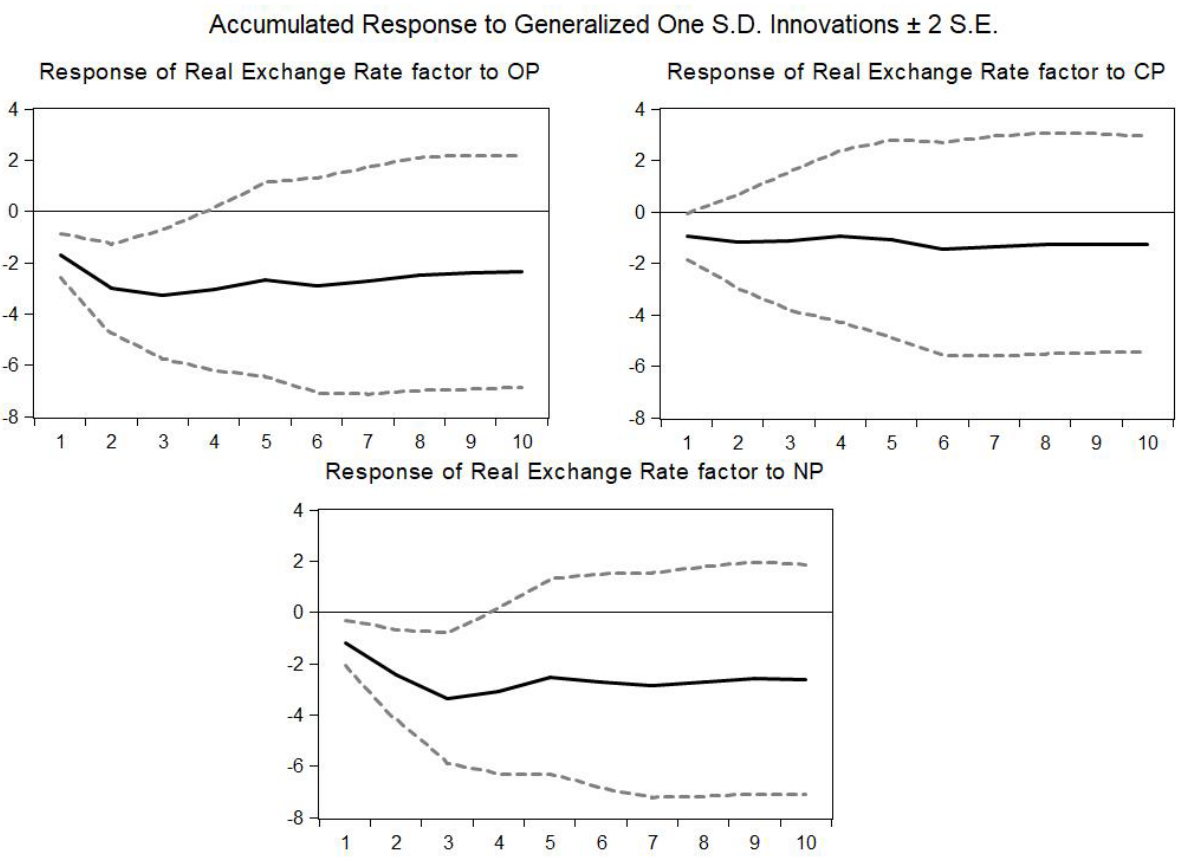

Source: Authors' own elaboration.

\subsection{Impact of Oil, Coal and Nickel Prices} on the Real Exchange Rate

The graph 4 allows us to observe that the RER presents a negative and significant response, with an approximate duration of three quarters from the shock. The effect that is generated is related to the high flow of foreign currency that enters, which appreciates the national currency. Oviedo and Sierra (2019) explain that the increase in the prices of exported goods creates an appreciation of the Colombian currency in the short term and the effect received by the sector benefiting from the boom is a function of its exposure to external markets and the composition of its inputs, both national and imported.

\subsection{Impact of Oil, Coal, and Nickel Prices on the Trade Balance}

The trade balance reacts significantly and positively to the increases in the prices of the three mining-energy goods, with a duration that extends for more than three quarters, as can be seen in Graph 5. The increase in the prices of exported products increases the national production of exported goods, that is to say, there is an increase in exports.

\subsection{Impact of Oil, Coal, and Nickel Prices on External Debt}

The graph 6 shows that foreign debt reacts significantly and negatively to the positive shocks of oil, coal, and nickel prices. The response spans approximately three quarters from the time the innovation is first introduced. This can be explained by the relationship between the external debt and the trade balance because the increase in exports reduces the trade balance deficit, which reduces the intentional indebtedness. It is also possible to deduce that, after the depreciation of the international currency, private companies, and the public sector decrease the number of their foreign debts.

\subsection{Impact of Oil, Coal, and Nickel}

Prices on the Unemployment Rate and Government Consumption

The graphic 7, shows that the shocks caused by the prices of energy mining 
Graph 5. The response of the trade balance to a positive shock in the prices of oil, coal, and nickel

Accumulated Response to Generalized One S.D. Innovations \pm 2 S.E.
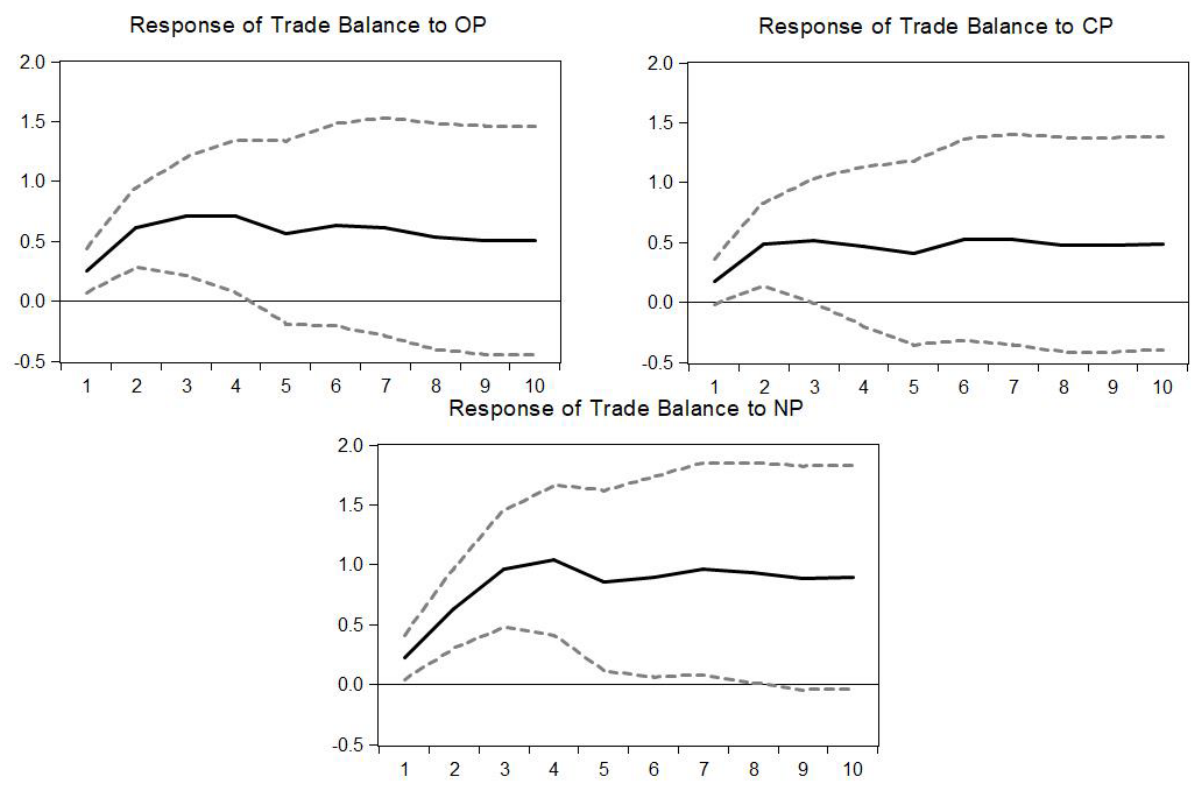

Source: Authors' own elaboration.

Graph 6. The response of the external debt to a positive shock in oil, coal, and nickel prices

Accumulated Response to Generalized One S.D. Innovations \pm 2 S.E.
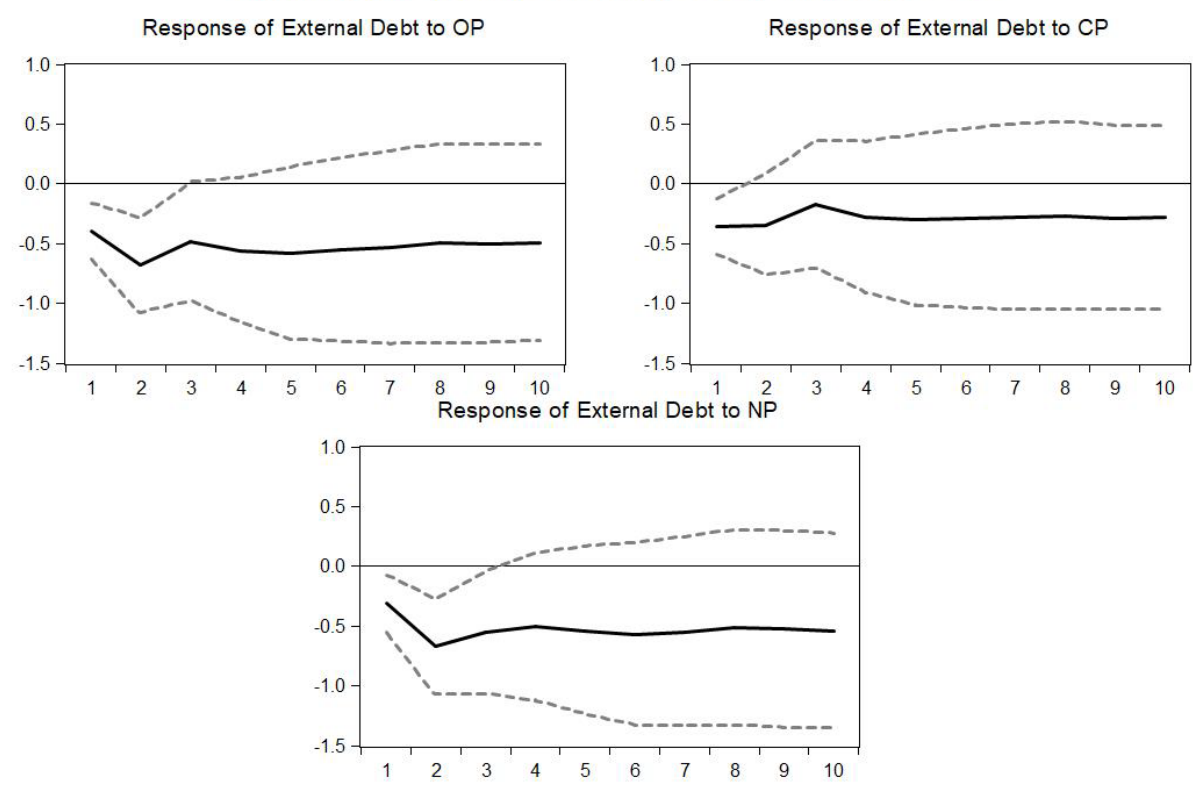

Source: Authors' own elaboration. 
Graph 7 The response of the unemployment rate and government consumption to a positive shock in oil, coal, and nickel prices

Accumulated Response to Generalized One S.D. Innovations \pm 2 S.E.

Response of Unemployment Rate to oP

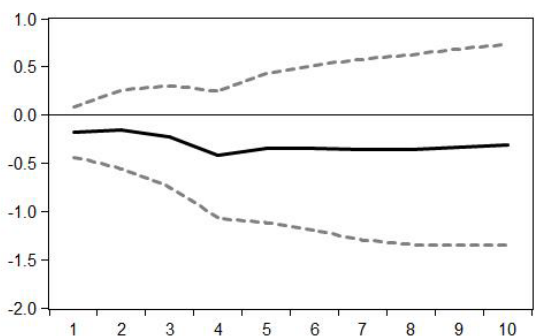

Response of Unemployment Rate to $\mathrm{CP}$

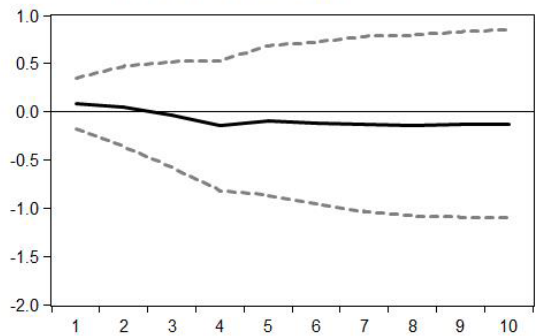

Response of Unemployment Rate to NP

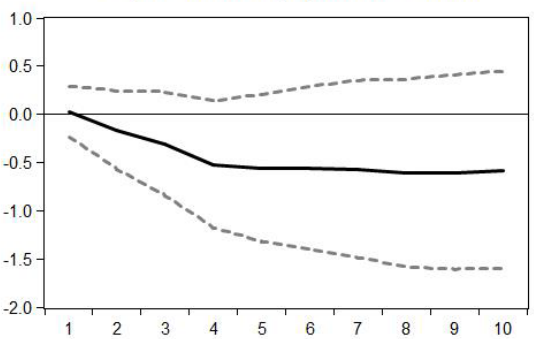

Response of Government Consumption to OP

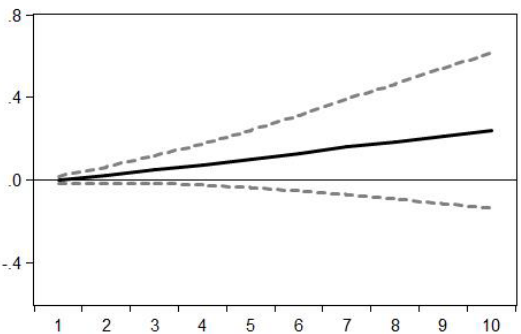

Response of Government Consumption to $\mathrm{CP}$

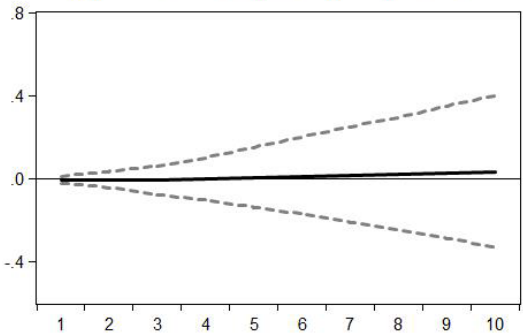

Response of Government Consumption to NP

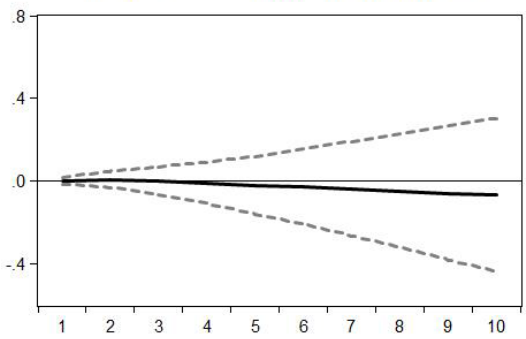

Source: Authors' own elaboration.

goods do not generate significant effects on the unemployment rate and government consumption. In the first place, the Colombian economy, having a strong dependence on oil production, receives high income through price increases, but these do not represent improvements in social development and mainly, they are not job generators given the inefficiency in the expense. Borge, Parmer, and Torvik (2015) explain that the increase in income from the exploitation of natural resources is associated with the inefficiency in spending and unemployment and a low level of economic growth is observed despite a high level of tax revenue generated by the mining-energy sector. For their part, Villar, Castro, Forero, Ramírez, and Reina (2014) describe, based on the construction of an input-product matrix, that the productive chains of the oil sector are not very significant and are visible, exclusively, in the same extractive sector, which shows the low incidence in the creation of employment in this sector, through intermediate consumption in other sectors. Second, the response of government consumption tends to be positive, but its impact is not statistically significant, because the government tends to save part of the income in cyclical moments where the price of oil reaches high levels so that in subsequent periods generate the effect of spending or dissaving (Perilla, 2010).

\subsection{Variance Decomposition}

Table 4 shows the variance decomposition ${ }^{10}$ where the percentage of variation generated 
Table 4. Variance Decomposition of the Selected Variables of Interest

\begin{tabular}{|l|c|c|r|}
\hline \multicolumn{4}{|c|}{ Percentage of the variance explained by the prices of: } \\
\hline \multicolumn{1}{|c|}{ Variables } & Oil & Coal & Nickel \\
\hline Economic Activity (GDP) & 7.6 & 4.0 & 1.9 \\
\hline Invesment & 5.4 & 4.0 & 10.2 \\
\hline Real Exchange Rate & 7.9 & 2.0 & 1.4 \\
\hline Trade Balance & 6.9 & 1.8 & 3.1 \\
\hline External Debt & 13.9 & 14.3 & 12.5 \\
\hline Unemployment Rate & 6.0 & 3.1 & 3.1 \\
\hline Government Consumption & 4.6 & 2.9 & 1.1 \\
\hline
\end{tabular}

by the fluctuations in the prices of the three raw materials studied on the economic aggregates is identified, for a finite horizon of 20 periods. The economic activity presented a variation between $1.9 \%$ and $7.6 \%$ due to fluctuations in commodities prices. On the other hand, investment shows variations between $4.0 \%$ and $10 \%$, while the exchange rate shows oscillations between $1.4 \%$ and $7.9 \%$. For its part, the trade balance varies between $1.8 \%$ and $6.9 \%$, the external debt between $12.5 \%$ and $14.3 \%$, the unemployment rate between $3.1 \%$ and $6 \%$, and government consumption between $1.1 \%$ and $4.6 \%$.

Most of the fluctuations in the economic aggregates observed are due to the behavior of oil prices, because of their great weight in national exports. The variables with the greatest fluctuation are economic activity, investment, the real exchange rate, trade trivialization, and foreign debt. Oviedo and Sierra (2019) found that investment was the variable that received the greatest amount of shock because of the improvement in the prices of exported goods improves the marginal profitability of the export sector. Also, it is observed that the external debt presents a significant decrease for each increase in the prices of these products, giving rise to an improvement in the benefits in the indebted sectors.

\section{Conclusions}

The main objective of this research was to evaluate the effects of the variations in the prices of mining and energy goods, with greater weight in Colombian exports, on the different economic aggregates. Also, it sought to give continuity to the study carried out by Oviedo and Sierra (2019), which made it possible to understand the incidents that TOT has on Colombian economic activity.

The impacts generated on the economy allow to conclude that a rise in the prices of these products generates an increase in the activity of the national economy and in investment, which is mostly focused on the oil sector due to its profitability, consequently, there is an increase in national exports, which reduces the trade deficit and, as a result, reduces the external debt. On the other hand, the boom in the commodities sector produces a revaluation of the Colombian peso because the increase in foreign currency inflows due to the dynamism of the mining-energy sector. In addition, this research shows indications that there is not a great benefit on the activity of the mining sector and on other indicators such as the unemployment rate and government consumption, which are fundamental for the improvement of the well-being of an economy. It is important to clarify that developing economies tend to generate a high dependence on the income of oil and / or other extractive mining-energy products, but the increase in spending does not imply improvements in employment or social investment, because the sector has a reduced demand for labor and even though the evidence does not show industrial deterioration due to Dutch disease, the economies that base their development on

10 The Cholesky orthogonalization method is used to orthogonalize the FAVAR residuals. 
the production of these products tend to have low levels of growth despite tax revenues from the petroleum.

The foregoing raises some questions about the targeting of the resources generated by this sector, because, and although an improvement in the economy is evident at the aggregate level, there are no positive effects on fundamental variables, which contribute to sectors such as the manufacturing industry and the services sector, which are intensive in labor and capital, which would allow economic growth with less dependence on variables exogenous to the system.

\section{Conflict of Interest}

The authors declare that there is no conflict of interest.

\section{Sources of Financing}

The research was carried out using the researchers' resources.

\section{References}

Bai, J., \& Ng, S. (2002). Determining the number of factors in approximate factor models. Econometrica, 70(1), 191-221. https://doi. org/10.1111/1468-0262.00273

Banco de la República. (2020). Exportaciones. Bogotá, Colombia: Banco de la República. Recuperado de https://www.banrep.gov.co/es/ estadisticas/exportaciones

Ben-Zeev, N., Pappa, E., \& Vicondoa, A. (2016). Emerging Economies Business Cycles: The Role of the Terms of Trade Revisited. BenGurion University of the Negev, (1610). https:// doi.org/10.1016/j.jinteco.2017.07.008

Bernanke, B. S., Boivin, J., \& Eliasz, P. (2005). Measuring the effects of monetary policy: a factor-augmented vector autoregressive (FAVAR) approach. The Quarterly Journal of Economics, 120(1), 387-422. https://doi. org/10.1162/0033553053327452

Bretschger, L. (2015). Energy prices, growth, and the channels in between: Theory and evidence. Resource and Energy Economics, 39, 29-52. https://doi.org/10.1016/j.reseneeco.2014.11.002
Borge, L. E., Parmer, P., \& Torvik, R. (2015). Local natural resource curse? Journal of Public Economics, 131, 101-114. https://doi. org/10.1016/j.jpubeco.2015.09.002

Candelo, J, M. (2018). Impactos indirectos de la tasa de cambio y los precios del petróleo en una economía no petrolera: aproximaciones VECM y VAR para el Valle del Cauca, Colombia. Finanzas y Política Económica, 10(2), 403-436. https://doi. org/10.14718/revfinanzpolitecon.2018.10.2.9

Cano, G., Vallejo, C., Caicedo, E., Amador, J., y Tique, E. (2012). El mercado mundial del café y su impacto en Colombia. Banco de la República, (710), 1-57. Recuperado de https://www. banrep.gov.co/sites/default/files/publicaciones/ archivos/be 710.pdf

Castillo, P., y Salas, J. (2010). Los términos de intercambio como impulsores de fluctuaciones económicas en economías en desarrollo: Estudio empírico. México DF, México: Centro de Estudios Monetarios Latinoamericanos. Recuperado de https://www.cemla.org/PDF/premiobc/pub-libpremio2010.pdf

Consejo Privadodela Competitividad(2014).Informe nacional de competitividad 2014-2015. Bogotá, Colombia: Consejo Privado de Competitividad. Recuperado de https://compite.com.co/informe/ informe-nacional-de-competitividad-2014-2015/

Fernández, A., González, A., \& Rodríguez, D. (2015). Sharing a Ride on the Commodities Roller Coaster: Common Factors in Business Cycles of Emerging Economies. Banco de la República, (915). Retrieved from https://www. banrep.gov.co/sites/default/files/publicaciones/ archivos/be 915.pdf

Geweke, J. (1976). The dynamic factor analysis of economic time series models. University of Wisconsin, 22(1), 37-54.

Gil, G. M. (2016). Impacto de los precios de los commodities en las economías suramericanas entre el 2000 y 2015. Medellín, Colombia. Universidad EAFIT. Recuperado de https://repository.eafit.edu.co/ bitstream/handle/10784/11267/GinaMaria GilCastro 2016.pdf?sequence $=2$ \&isAllowed $=y$

Gómez, C. (2015). Más allá de un boom de recursos naturales: efectos de los choques petroleros en la economía colombiana. Recuperado de https:// ideas.repec.org/p/col/000089/012565.html

Gómez, V., \& Maravall, A. (2001). Seasonal adjustment and signal extraction in economic time series ( $\mathrm{N}^{\circ}$ 9809, pp. 202-246). España: 
Banco de España - Servicio de Estudios. Recuperado de https://www.bde.es/f/ webbde/SES/Secciones/Publicaciones/

PublicacionesSeriadas/DocumentosTrabajo/98/ Fic/dt9809e.pdf

González, S., y Hernández, E. (2016). Impactos indirectos de los precios del petróleo en el crecimiento económico colombiano. Lecturas de Economía, 84, 103-141. https://dx.doi. org/10.17533/udea.le.n84a04

Hamilton, J. D. (1988). A neoclassical model of unemployment and the business cycle. Journal of political Economy, 96(3), 593-617. https:/l www.jstor.org/stable/1830361

Hernández, G. (2013). Colombia: Términos de intercambio y fluctuaciones de la producción. Revista CEPAL, (110), 109-131. Recuperado de https://repositorio.cepal.org/ bitstream/handle/11362/11617/110113136 es.pdf? sequence $=1$ \&isAllowed $=\mathrm{y}$

Jenkins, R. O. (2011). The "China effect" on commodity prices and Latin American export earnings. CEPAL Review, (103), 73- 87. Recuperado de https://repositorio.cepal.org/ bitstream/handle/11362/11471/103073087I en.pdf? sequence $=1 \&$ is Allowed $=y$

Lee, K., \& Ni, S. (2002). On the dynamic effects of oil price shocks: a study using industry level data. Journal of Monetary economics, 49(4), 823-852. https://doi.org/10.1016/S0304-3932(02)00114-9

Lilien, D. M. (1982). Sectoral shifts and cyclical unemployment. Journal of political economy, 90(4), 777-793. Retrieved from https://www. jstor.org/stable/1831352

Mendoza, E. G. (1995). The terms of trade, the real exchange rate, and economic fluctuations. International Economic Review, 36(1), 101137. Retrieved from https://www.jstor.org/ stable/2527429

Medina, L. (2010). The Dynamic Effects of Commodity Priceson Fiscal Performance in Latin America. International Monetary Fund, 10-192. Retrieved from https://www.imf.org/ en/Publications/WP/Issues/2016/12/31/TheDynamic-Effects-of-Commodity-Prices-onFiscal-Performance-in-Latin-America-24159

Oviedo, A. F., y Sierra, L. P. (2019). Importancia de los términos de intercambio en la economía colombiana. Revista CEPAL, (128), 125-154. Recuperado de https://repositorio.cepal.org/ bitstream/handle/11362/44740/1/RVE128 Oviedo.pdf
Parra, J. C. (2008). Hechos Estilizados de la Economía Colombiana: Fundamentos Empíricos para la Construcción y Evaluación de un Modelo DSGE. Borradores de Economía, Banco de la República, (509), 1-47. Recuperado de https://www.banrep.gov.co/sites/default/ files/publicaciones/pdfs/borra509.pdf

Peña, C. (2008). Choques petroleros, incertidumbre e inversión privada. Venezuela, 1968-2007. Perfil de Coyuntura Económica, (11), 51-74. Recuperado de https://ideas.repec.org/a/ col/000165/005319.html

Peña, C. (2015). Desempleo, inversión y términos de intercambio. Venezuela 1970-2012. Perfil de Coyuntura Económica, (25), 141-163. Recuperado de https://www.redalyc.org/ pdf/861/86145265008.pdf

Perilla, J. R. (2010). El impacto de los precios del petróleo sobre el crecimiento económico de Colombia. Revista de economía del Rosario, 13(1), 75-116. Recuperado de https://revistas. urosario.edu.co/index.php/economia/article/ view/1631

Poncela, P., Senra, E., \& Sierra, L. P. (2016). Longterm links between raw materials prices, real exchange rate and relative de-industrialization in a commodity-dependent economy: empirical evidence of "Dutch disease" in Colombia. Empirical Economics, 52(2), 777-798. https://doi. org/10.1007/s00181-016-1083-7

Regnier, E. (2007). Oil and energy price volatility. Energy economics, 29(3), 405-427. https://doi. org/10.1016/j.eneco.2005.11.003

Schmitt-Grohé, S., \& Uribe, M. (2015). How Important Are Terms of Trade Shocks? National Bureau of Economic Research, (w21253), 1-37. Retrieved from https://www.nber.org/papers/ w21253.pdf

Sinnott, E., Nash, J., y de la Torre, A. (2010). Natural resources in Latin America and the Caribbean: beyond booms and busts? Washington, D.C., United States, World Bank Publication.

Spatafora, N., \& Warner, A. M. (1999). Macroeconomic and sectorial effects of terms-oftrade shocks: the experience of the oil-exporting developing countries. Washington, Estados Unidos: IMF. Retrieved from https://www.imf. org/external/pubs/ft/wp/1999/wp99134.pdf

Stock,J.H., \& Watson, M.W. (2002). Macroeconomic forecasting using diffusion indexes. Journal of Business \& Economic Statistics, 20(2), 147-162. https://doi.org/10.1198/073500102317351921 
Stock, J. H., \& Watson, M. W. (2005). Implications of dynamic factor models for VAR analysis. National Bureau of Economic Research, 11467, 1-67. Retrieved from https://scholar.harvard.edu/files/stock/files/ implicationsdynamicfactormodels.pdf

Stock, J. H., \& Watson, M. W. (2011). Dynamic factor models. Oxford handbook of economic for recasting, 1, 35-59. Retrieved from https://www. princeton.edu/ mwatson/papers/dfm_oup 4 . pdf

The World Bank Group. (2016). World Development Indicators: Exports of goods and services (\% of $G D P)$. Retrieved from http://databank.worldbank. org/data/reports.aspx?Code=NE.EXP.GNFS.
ZS\&id=af3ce82b\&report_name $=$ Popular indicators\&populartype $=$ series \&ispopular $=y$

Vargas, H. (2015). Choques macroeconómicos y retos de la política monetaria 2014-2015. Serie: Discursos y presentaciones, Banco de la República. 1-20. Recuperado de https://www. banrep.gov.co/sites/default/files/publicaciones/ archivos/hvh nov 2015.pdf

Villar, L., Castro, F., Forero, D., Ramírez, J., y Reina, M. (2014). Evaluación de la contribución económica del sector de hidrocarburos colombiano frente a diversos escenarios de producción. Fedesarrollo. Recuperado de https://www.repository.fedesarrollo.org.co/ $\underline{\text { handle/11445/1688 }}$

How to cite this paper?

Oviedo-Gómez, A., Candelo-Viafara, J. M. (2020). Mining and Energy Commodity Price Effects on Colombian Economy. Cuadernos de Administración, 36(67), 93-108. https://doi.org/10.25100/cdea.v36i67.8641 
Annex A1 contains the information on the number of lags according to the selection criteria for the estimated models. Finally, two lags were used since for this value the model is robust and consistent in the evaluation of the assumptions about the residuals. On the other hand, Annex A2 shows the autocorrelation test (LM test) on the residuals for the estimated models.

\begin{tabular}{|l|c|c|c|c|c|}
\hline \multicolumn{5}{|c|}{ Annex A1. Lag Selection Criteria } \\
\hline Criteria & LR & FPE & AIC & SC & HQ \\
\hline Number of lags & 1 & 2 & 1 & 2 \\
\hline $\begin{array}{l}\text { LR: Likelihood-ratio test; FPE: Final Prediction Error; AIC: Akaike Information Criteria; SC: Schwarz Information Criteria; HQ: } \\
\text { Hannan-Quinn Information Criteria. }\end{array}$ \\
\hline \multicolumn{4}{|l|}{ Source: Own calculations. } \\
\hline
\end{tabular}

\begin{tabular}{|c|c|c|}
\hline \multicolumn{3}{|c|}{ Annex A2. Autocorrelation Test (LM test) } \\
\hline Period & LM-Stat & p-value \\
\hline 1 & 99.07817 & 0.5073 \\
\hline 2 & 99.22208 & 0.5032 \\
\hline 3 & 91.64744 & 0.7124 \\
\hline 4 & 115.1161 & 0.1432 \\
\hline 5 & 87.98985 & 0.7990 \\
\hline 6 & 92.18989 & 0.6984 \\
\hline 7 & 101.0585 & 0.4516 \\
\hline \multicolumn{3}{|c|}{$\begin{array}{l}\text { Note: null hypothesis: there is no correlation in th } \\
\text { residuals. }\end{array}$} \\
\hline \multicolumn{3}{|c|}{ Source: Own calculations. } \\
\hline
\end{tabular}

\begin{tabular}{|l|c|c|}
\hline \multicolumn{3}{|c|}{ Annex A3. Normality Tests } \\
\hline \multirow{2}{*}{ Normality Test (Jarque-Bera) } & Estatistical & p-value \\
\cline { 2 - 3 } & 28.32268 & 0.1020 \\
\hline $\begin{array}{l}\text { Note: null hypothesis normality test: Normality in the } \\
\text { errors. }\end{array}$ \\
\hline \multicolumn{3}{|c|}{ Source: Own calculations. } \\
\hline
\end{tabular}

\begin{tabular}{|l|c|c|}
\hline \multicolumn{3}{|c|}{ Annex A4. Heteroscedasticity Tests } \\
\hline \multirow{2}{*}{ White's Heteroscedasticity Tests } & Chi-sq & p-value \\
\cline { 2 - 3 } & 2227.230 & 0.3377 \\
\hline $\begin{array}{l}\text { Note: null hypothesis Heteroscedasticity test: the errors } \\
\text { are homoscedastic. }\end{array}$ \\
\hline \multicolumn{3}{|c|}{ Source: Own calculations. } \\
\hline
\end{tabular}

